\title{
AKTIVITAS IMUNOMODULATOR EKSTRAK DAUN Moringa oleifera Lam TERHADAP POPULASI HEMATOPOETIC STEM CELL PADA MENCIT YANG DIINFEKSI Salmonella typhi
}

\author{
Mohammad Hefni, Muhaimin Rifa'i, dan Widodo
}

Laboratorium Fisiologi Hewan

Jurusan Biologi, Fakultas Matematika dan Ilmu Pengetahuan Alam, Universitas Brawijaya

Email: hefnis2bio@gmail.com

\begin{abstract}
Abstrak
Tujuan penelitian ini untuk mengetahui aktivitas imunomodulator ekstrak daun Moringa oleifera Lam terhadap populasi Hematopoetic Stem Cell (HSC) pada mencit yang diinfeksi Salmonella typhi.Mencit dikelompokkan menjadi 2 kelompok.Kelompok non-infeksi dan kelompok infeksi S. typhi.Pada masing-masing kelompok diberikan ekstrak M. oleifera secara oral selama 20 hari dengan dosis yang berbeda, diantaranya kelompok kontrol (0 $\mathrm{mg} / \mathrm{kg} \mathrm{BB})$, dosis 1 (14 mg/kg BB), dosis 2 (42 mg/kg BB), dan dosis 3 (84 mg/kg BB).Selanjutnya pada kelompok infeksi diinfeksi S. typhi sebanyak $10^{8}$ sel.Jumlah populasi HSC dapat diketahui dengan mengamati molekul permukaan HSC (Cluster of Differentiation 34/ CD34)dengan analisa software BD CellQuest Flowcytometri.Data hasil flowcytometri dianalisis menggunakan Two-Way Anova $(P<0.05)$, dengan SPSS 16.0 for Windows. Hasil penelitian menunjukkan pemberian ekstrak M. oleifera dapat beraktivitas sebagai imunostimulator terhadap HSC (CD34),namun pemberian dengan dosis rendah (14 dan $42 \mathrm{mg} / \mathrm{kg}$ BB) lebih efektif dibandingkan dengan dosis tinggi ( $84 \mathrm{mg} / \mathrm{kg} \mathrm{BB}$ ). Bahkan, pemberian ekstrak M. oleiferadengan dosis tinggi (84 mg/kg BB) dapat beraktivitas sebagai imunosupresor terhadap HSC
\end{abstract}

Kata kunci:Moringa oleifera, Salmonella typhi, Hematopoetic Stem Cell.

\section{PENDAHULUAN}

Agen infeksi maupun non-infeksi banyak terdapat di lingkungan sekitar kita, yang setiap saat dapat menyerang host cell maupun jaringan. Agen infeksi tersebut dapat berupa bakteri patogen intraseluler,dalam jumlah tertentu dapat menginfeksi dan bermultiplikasi di dalam tubuhyang akan menyebabkan penyakit serius pada hewan maupun manusia dalam keadaan immunodeficiency.

Salah satu bakteri patogen intraseluler diperankan oleh kelompok bakteri dari genus Salmonella. Menurut Zang, et al. (2008)Salmonella merupakan agen penyebab penyakit salmonellosis. Bakteri ini termasuk ke dalam famili Enterobacteriaceae, berbentuk batang, berflagel (Pui et al., 2011) dan termasuk dalam golongan bakteri gram negatif anaerob fakultatif. Bakteri dari golongan Salmonella ini mampu menyerang hewan dan manusia dengan berbagai level infeksi yang bervariasi,mulai infeksi ringan yang mengakibatkan diare sampai pada infeksi tingkat tinggi seperti demam tifoid (Deipen $e t$ al., 2005).Infeksi tingkat tinggi tersebut diperankan oleh spesies Salmonella typhi (Deipen et al., 2005). Gejala infeksi S. typhi dapat menyebabkan penyakit infeksi sistemik yang parah, serta juga dapat menyerang sel-sel host, terutama menyerang dan bereplikasi dalam sel makrofag. Salmonellajuga mempunyai faktor virulensi utama yang berupa lipopolisakarida (LPS) (Torres et al., 2000). Jika pertahanan sel-sel host tidak mencukupi, maka infeksi yang ditimbulkan akan berdampak pada organ-organ vital termasuk pada sumsum tulang (Bone marrow), kelenjar gatah bening (limph node), dan limfa (spleen) (Eckmann et al., 2001).

Pecegahan sedini mungkin perlu dilakukan untuk mengantisipasi adanya infeksi bakteri patogen (S. typhi) dengan cara 
meningkatkan sistem imunitas baik humoral maupun seluler. Sel-sel imunitas yang berperan penting dalam sistem imunitas diperankan oleh Hematopoeitic Stem Cell(CD34) yang terdapat pada bone marrow.Sel pluripoten ini dapat membelah menjadi dua tipe stem cell yaitu limfoid progenitor dan mieloid progenitor yang berperan dalam meregulasi sistem imun baik humoral maupun selular.

Limfoid progenitor berkembang manjadi sel limfosit $\mathrm{B}$ dan $\mathrm{T}$ yang masing-masing berfungsi sebagai sistem imunitas humoral dan selular dalam sistem imunitas adaptive. Sedangkan meiloid progenitor berkembang sebagai leukosit, eritrosit, makrofag, dendritik, monosit, dan megakariosit yang memproduksi platelet yang penting dalam pembekuan darah (Hoffbrand, 2005).

Peningkatan imunitas ini dapat dilakukan dengan terapi pemberian obatobatan herbal untuk meminimalisir adanya resistensi terhadap bakteri target. Obat-obatan herbal dapat berasal dari buah, sayur, maupun tanaman yang memiliki kandungan sebagai imunomodulator (memodulasi fungsi dan aktivitas sistem imun).Salah satu tanaman yang memiliki kandungan imunomodulator yaitu Moringa oleifera.M. oleiferatermasuk dalam famili Moringaceae, banyak tersebar di negara yang beriklim tropis dan sub-tropis termasuk di Indonesia.Menurut Kasolo et al.(2010) kandungan fitokimia daun M. oleifera Lam meliputi senyawa gallic tannin, steroids, titerpenoid, flavonoid, saponin, antraquinones, catecol tannin, alkaloid dan reducing sugar, dan alkaloid..Kandungan fitokimia $M$. oleiferaini dapat bermanfaat dalam meningkatkan titer antibodi (Sudha et al., 2010), meningkatkan konsentrasi leukosit, eritrosit, haemoglobin level $(\mathrm{Hb})$, persentase neutrofil, berat organ timus dan spleen (Gupta et al., 2010).

Berdasarkan fenomena tersebut, maka penelitian ini bertujuan untuk mengetahui aktivitas imunomodulator ekstrak M. oleifera.terhadap populasi Hematopoeitic Stem Cell pada mencit yang diinfeksi $S$. typhi.Populasi Hematopoeitic Stem Celldapat diketahui dengan cara mengamati molekul permukaan CD (Cluster of Differentiation) dari HSC berupa CD34. Abbas (2005) mengungkapkan bahwa, $\mathrm{CD} 34^{+}$merupakan marker pertama yang dapat digunakan untuk mengetahui jumlah HSC perimitive pada sumsum tulang atau darah perifer.

\section{METODE PENELITIAN \\ Waktu dan Tempat Penelitian}

Penelitian ini dilaksanakan pada bulan Juni-November 2012 yang bertempat di Laboratorium Biologi FMIPA Universitas Brawijaya Malang, meliputi Laboratorium Fisiologi Hewan, Laboratorium Mikrobiologi, Laboratorium Biologi Molekuler, dan Laboratorium Biomedik Fakultas Kedokteran Universitas Brawijaya Malang.

\section{Populasi dan Sampel}

Populasi sampel yang digunakan sebanyak 8 perlakuan dengan 3 ulangan. Hewan coba yang digunakan dalam penelitian ini adalah mencit (Mus musculus)pathogen freestrain Deutschland Denken Yonken (DDY)jenis kelamin betina dengan umur 7 minggu dengan rata-rata berat badan 26 gram.Sampel bakteri yang digunakan sebagai agen infeksi yaitu berupa Salmonella thyphi yang diperoleh dari Laboratorium Mikrobiologi Fakultas Kedokteran Universitas Brawijaya.Daun Moringa oleifera Lam yang digunakan dalam penelitian ini diperoleh dari desa Karduluk, Kecamatan Paragaan, Kabupaten Sumenep.

\section{Pengelompokan Perlakuan Hewan Coba}

Hewan coba berupa mencit sebanyak 32 ekor dibagi menjadi 8 kelompok perlakuan, masing-masing kelompok terdiri dari 4 ekor.Mencit diaklimasi selama 1 minggu, selanjutnya dibagi menjadi dua sub-kelompok (kelompok infeksi dan non-infeksi).Pada masing-masing kelompok digunakan 3 variasi dosis yang berbeda Tabel 1 .

\section{Pemberian dan Ekstraksi M. oleifera}

Pemberian Ekstrak $M$. oleifera dilakukan secara oral 1 kali sehari selama 20 hari sesuai dosis perlakuan menggunakan sonde.Volume pemberian ekstrak M. oleifera sebanyak100 $\mu \mathrm{l}$ dengan tambahan pelarut NaCMC $0.05 \%$.

Pembuatan ekstraksi air daun $M$. oleifera dilakukan dengan cara mengambil daun $M$. oleifera yang sudah dewasa (3-5 dari pangkal atau batang utama), selanjutnya dicuci hingga bersih. Daun M. oleifera yang sudah bersih dikering anginkan dan diblender,hasil blender kemudian diayak sehingga didapatkan serbuk (simplisia). 5 gram simplisia dilarutkan dengan $50 \mathrm{ml}$ aquades dan dilakukan maserasi selama 15 menit sambil sesekali diaduk. 
Selanjutnya dipanaskan pada suhu $80^{\circ} \mathrm{C}$ selama 15 menit. Kemudian dilakukan penyaringan dengan menggunakan kain flanel dan kertas saring, dandidapatkan infusa. Infusa yang diperoleh ditambah aquades sampai mencapai $50 \mathrm{ml}$. Infusa yang diperoleh merupakan hasil ekstraksi dengan konsentrasi 10 kali pengenceran, dan selanjutnya digunakan sesuai dosis perlakuan.

\section{Injeksi S. thypi}

Injeksi S. typhi dilakukan secara intrapretoneal pada hari ke-21 sebanyak $10^{8}$ $\mathrm{sel} / \mathrm{ml}$ setelah pemberian esktrak $M$. oleifera.Injeksi dilakukan dengan mengambil S. thypi dari biakan murni dibiakkan pada 20 $\mathrm{ml}$ mediumLB (Luria Broth), diinkubasi sampai mencapai jumlah $10^{8} \mathrm{sel} / \mathrm{ml}$ dengan melakukan perhitungan dengan hemacytometer setiap 1 jam. Setiap melakukan perhitungan jumlah sel/ml ditambahkan 1-4 tetes formalin $4 \%$ dan dilakukan dengan proses penghitungan bakteri dengan menggunakan hemacytometer, sampaimendapatkan konsentrasi sel bakteri $10^{8} \mathrm{sel} / \mathrm{ml}$. Selanjutnya dilakukan setrifugasi dengan kecepatan 10.000 rpm selama 10 menit pada suhu $25^{\circ} \mathrm{C}$. Pelet yang diperoleh disuspensi dengan larutan PBS for injection atau $\mathrm{NaCl}$ fis sebanyak $100 \mu \mathrm{l}$. Suspensi tersebut diinjeksikan pada hewan coba secara intrapretoneal.

\section{Uji Konfirmasi S. typhi dalam Darah Mencit} Konfirmasi keberadaan S. typhi di dalam darah dilakukan setelah 24 jam perlakuan infeksi $S$. typhi untuk memastikan keberadaan bakteri setelah infeksi. Uji konfirmasi ini dilakukan dengan mengambil darah mencit melaui pembuluh vena caudalis (ekor).Mula-mula mencit dimasukkan dalam penyungkup dan ekornya dioles dengan alkohol 70\%.Selanjutnya ekor mencit dipotong $\pm 2 \mathrm{~mm}$ dari ujung ekor.Tetesan darah yang keluar pertama kali diusap dengan tissue, selanjutnya ekor diurut dari pangkal hingga ujung secara perlahan. Tetesan darah ditampung dalam microtube yang telah disisi dengan antikoagulan hingga mencapai volume $50 \mu 1$. Selanjutnya ditambah dengan larutas $\mathrm{NaCl}$ fis steril sebanyak $450 \mu$ l. Darah hasil isolasi kemudian ditanam pada media LB dan diinkubasi dalam ikubator shaker selama 24 jam pada suhu $37{ }^{\circ} \mathrm{C}, 120 \mathrm{rpm}$.

Hasil isolasi pada media LB kemudian diinokulasikan pada media selektif
Salmonella yaitu media XLD (Xylose-LysineDeoxycholate). Pada medium ini, Samonella akan membentuk koloni dan akan menghasilkan warna hitam. Konfirmasi bakteri uji selanjutnya dilakukan dengan uji katalase. Salmonella akan menunjukkan positif katalase. Uji katalase ini dilakukan dengan mengambil satu ose biakan bakteri dan direaksikan dengan $\mathrm{H}_{2} \mathrm{O}_{2}$ yang sebelumnya diteteskan pada kaca objek. Hasil positif ditunjukkan dengan adanya gelembung yang menunjukkan $\mathrm{H}_{2} \mathrm{O}_{2}$ telah dipecah oleh isolat bakteri tersebut menjadi $\mathrm{H}_{2} \mathrm{O}$ dan $\mathrm{O}_{2}$ dengan reasksi $\left(\mathrm{H}_{2} \mathrm{O}_{2} \rightarrow \mathrm{H}_{2} \mathrm{O}+\frac{i}{2} \mathrm{O}_{2}\right)$.

\section{Pembedahan dan Isolasi Sel}

Mencit dilakukan pembedahan pada hari ke-34. Mula-mula mencit dibunuh dengan cara dislokasi leher, hal ini memungkinkan mecit tidak merasakan sakit pada saat pembedahan. Kemudian dilakukan penyayatan pada daerah abdomen mencit, selanjutnya dilakukan pengambilan organ bone marrow untuk diisolasi selnya.

Isolasi sel dari bone marrow dilakukan dengan cara mengambil dari tulang femur, dan tibia. Tulang femur dan tibia pada mencit terlebih dahulu dibersihkan dari sisa jaringan otot yang menempel kemudian diflush dengan PBS menggunakan jarum 27 G. Selanjutnya dihomogenkan dengan cara pipeting. Hasil isolasi sel ditambah sampai mencapai volume $6 \mathrm{ml}$ dan dimasukkan ke dalam tabung falcon untuk selanjutnya disentrifugasi dengan kecepatan $1500 \mathrm{rpm}$, pada suhu $20^{\circ} \mathrm{C}$ selama 5 menit.Pellet yang dihasilkan disuspensi dengan $1 \mathrm{ml}$ PBS dan dipipeting untuk mendapatkan homogenat. Sebanyak $200 \mu \mathrm{l}$ homogenat dipindahkan pada tabung mikrosentrifus baru dan ditambahkan 500 ul PBS. Selanjutnya disentrifugasi dengan kecepatan $1500 \mathrm{rpm}$ selama 5 menit pada suhu $20^{\circ} \mathrm{C}$. Hasil supernatan dibuang dan pelletnya ditambahkan Antibodi untuk selanjutnya dianalisis dengan flowcytometri.

\section{Penghitungan Jumlah Sel}

Penghitungan jumlah sel dilakukan untuk mengetahui jumlah absolut sel pada masing-masing organ yang diambil dalam penelitian ini, yaitu bone marrow dan spleen.Penghitungan jumlah sel dilakukan dengan menggunakan haemocytometer. Suspensi sel hasil isolasi dalam PBS diwarnai dengan pewarnaan evens blue. Sel yang 
dihitung adalah sel hidup yang ditandai dengan tidak terwarnai oleh evens blue.

Suspensi sel hasil isolasi dihitung dengan pengenceran 10 kali, dengan cara mengambil $10 \mu \mathrm{l}$ dan dimasukkan ke dalam microtube, selanjutnya ditambahkan $90 \mu \mathrm{l}$ even Blue dan dihomogenkan. Penghitungan sel dilakukan terhadap sel hidup yang terdapat pada 5 kotak sedang pada heamocytometer dengan menggunakan rumus:

$$
\sum=\frac{\mathrm{n.Fp}}{0.02}=\ldots \ldots . . . \times 10^{3} \mathrm{sel} / \mathrm{ml}
$$

Ket $: \sum=$ Jumlah sel keseluruhan $\mathrm{n}=$ jumlah sel dari 5 bilik hitung FP $=$ Faktor Pengenceran

\section{Analisis Flowcytometri}

Analisis flowcytometri dilakukan untuk mengetahui jumlah populasi HSC(CD34) pada bone marrow. Sel homogenat yang diisolasi dari bone marrowdiinkubasi dengan antibodi rat anti-mouse anti-CD34PE conjugated. Masa inkubasi dilakukan \pm 15 menit pada suhu $4^{\circ} \mathrm{C}$.Penambahan sel homogenat dengan antibodi, digunakan perbandingan 1:500. Sampel yang telah diinkubasi antibodi ditambah dengan $3 \mathrm{ml}$ PBS selanjutnya ditempatkan pada kuvet flowcytometri. Flowciytometri disetting sesuai dengan prameter yang akan dianalisis.

\section{Analisis Data}

\section{Analisis Data Hasil Flowcytometri}

Data hasil dari flowcytometri dianalisa dengan menggunakan sofwer BD cellquest Pro $^{\mathrm{TM}}$.Program diatur sesuai dengan pewarnaan dan jenis sel yang diidentifikasi.Gated dilakukan berdasarakan pola ekspresi sel yang terlihat dalam layar komputer.

\section{Analisis Statistik}

Data hasil analisa dengan menggunakan sofwer BD cellquest Pro $^{\mathrm{TM}}$ selanjutnya ditabulasi dan dianalisis dengan menggunakan uji statistik two-way ANOVA (Analysis of Variance) melalui program SPSS 16.0.apabila $\mathrm{P}<0,05$, hal ini menunjukkan perbedaan yang signifikan antara kelompok perlakuan, sehingga dilanjutkan dengan uji lanjutTukey.

\section{HASIL}

Hasil rerata analisis flowcytometri pada (Gambar 1) menunjukkan bahwa pada kelompok perlakuan pemberian ekstrak daun $M$. oleifera dengan model non-infeksi $S$. typhi dapat meningkatkan persentase CD34 dibandingkan dengan kelompok kontrol. Terbukti pada $\mathrm{P} 1(-)$ (dosis $14 \mathrm{mg} / \mathrm{Kg} \mathrm{BB}$ ) diperoleh persentase $\mathrm{CD} 34^{+}$sebanyak 3,19\%, P2(-) (dosis $42 \mathrm{mg} / \mathrm{Kg} \mathrm{BB}$ ) 4,32\%, dan P3(-) (dosis $84 \mathrm{mg} / \mathrm{Kg}$ BB) 2,96\%, hal ini menandakan adanya peingkatan jumlah persentase CD34 apabila dibandingkan dengan kelompok K(-) (dosis 0 mg/Kg BB) 2,60\%.

Pada perlakuan pemberian ekstrak air daun $M$. oleifera dengan model infeksi S. typhi (Gambar 1) menunjukkan hasil persentase yang relatif sama antar perlakuan, yakni pada $\mathrm{K}(+)$ (dosis $0 \mathrm{mg} / \mathrm{Kg} \mathrm{BB}$ ) persentase $\mathrm{CD} 34$ sebanyak 2,07\%, P1(+) (dosis $14 \mathrm{mg} / \mathrm{Kg} \mathrm{BB})$ sebanyak 2,11\%, P2(+) (dosis $42 \mathrm{mg} / \mathrm{Kg} \mathrm{BB}$ ) sebanyak 2,22\%, dan P3(+) (dosis $84 \mathrm{mg} / \mathrm{Kg}$ BB) sebanyak 2,35\%.

Jumlah persentase flowcytometri ini menggambarkan jumlah persentase sel yang hanya mengeskpresikan CD34 dari jumlah sel yang terbaca pada alat flowcytometri \pm 10.000 sel/ sampel. Oleh karena itu, untuk mengetahui jumlah sel CD34 di seluruh sumsum tulang/ bone marrow dilakukan perhitungan secara absolut sel dengan cara menghitung sel/ml dari hasil isolasi sel bone marrowdengan menggunakan hemacytometer.

Berdasarkan hasil perhitungan jumlah absolut sel CD34disajikan pada (Tabel2) dapat diketahui bahwa, jumlah absolut sel CD34 pada perlakuan pemberian ekstrak air $M$. oleifera Lam dengan model infeksi dan noninfeksi $S$. typhi terdapat perbedaan yang signifikan antar perlakuan $(P$ Value $<0.05)$.

Hasil uji lanjut menggunakan Tukey (Gambar 2)menunjukkan bahwa, pada kelompok perlakuan pemberian ekstrak daun $M$. oleifera dengan model non-infeksi diketahui pada kelompok P1(-) (dosis 14 $\mathrm{mg} / \mathrm{kg}$ BB)jumlah populasi selCD34667329 sel/ml dan P2(-) (dosis $14 \mathrm{mg} / \mathrm{Kg} \mathrm{BB}$ ) jumlah sel $\mathrm{CD}^{+} 4^{+}$sebanyak $1083753 \mathrm{sel} / \mathrm{ml}$, menunjukkan jumlahlebih tinggi bila dibandingkan dengan kelompok $\mathrm{K}(-)$ (dosis 0 $\mathrm{mg} / \mathrm{Kg}$ BB) $591665 \mathrm{sel} / \mathrm{ml}$. Namun pada kelompok P3(-) (Dosis $84 \mathrm{mg} / \mathrm{kg} \mathrm{BB}$ ) jumlah sel CD34mengalami penurunan dibandingkan dengan K(-), yaitu $518571 \mathrm{sel} / \mathrm{ml}$. Fenomena ini mengindikasikan adanya aktivitas 
imunostimulator yang diperankan oleh ekstrak daun $M$. oleifera pada dosis rendah (14 dan 42 $\mathrm{mg} / \mathrm{kg} \mathrm{BB}$ ), sedangkan dosis tinggi $(84 \mathrm{mg} / \mathrm{kg}$ BB) pada penelitian ini bertindak sebagai imunosupresor.

Pada perlakuan pemberian ekstrak daun $M$. oleifera Lam dengan model infeksi $S$. typhijumlah sel CD34 meningkat secara siginifikan(Gambar 2). Jumlah sel CD34 pada masing-masing kelompok perlakuan $\mathrm{P} 1(+)$ (dosis $14 \mathrm{mg} / \mathrm{Kg} \mathrm{BB}$ )sebanyak $510413 \mathrm{sel} / \mathrm{ml}$, $\mathrm{P} 2(+)$ (dosis $14 \mathrm{mg} / \mathrm{Kg} \mathrm{BB}$ ) sebanyak 366723 $\mathrm{sel} / \mathrm{ml}$, dan $\mathrm{P} 3(+)$ (dosis $84 \mathrm{mg} / \mathrm{Kg} \quad \mathrm{BB}$ ) sebanyak $478882 \mathrm{sel} / \mathrm{ml}$ menunjukkan angka yang lebih tinggi bila dibandingkan dengan kelompok yang hanya diinfeksi $S$. typhi $\mathrm{K}(+) 186274 \mathrm{sel} / \mathrm{ml}$.

\section{PEMBAHASAN}

Sub-bab dalam penelitian ini akan membahas jumlah populasi sel induk pluripoten atau Hematopoietic Stem Cells (HSC) padabone marrow setelah pemberian ekstrak air daun Moringa oleifera Lam dengan model non-infeksi dan infeksi Salmonella typhi. Populasi HSC penting untuk diketahui karena termasuk salah satu organ sentral limfoid yang berperan dalam sistem imunitas.

Penggunaan $M$. oleifera sebagai agen imunomodulator didasarkan pada kemampuaannya dalam meregulasi sistem imunitas.Wiedosari (2007) mendefinisikan, imunomodulator merupakan substansi atau obat yang dapat memodulasi fungsi dan aktivitas sistem imun. Imunomodulator dibagi menjadi 3 kelompok: i) imunostimulator, berfungsi untuk meningkatkan fungsi dan aktivitas sistem imun, ii) imunoregulator, artinya dapat meregulasi sistem imun, dan iii) imunosupresor yang dapat menghambat atau menekan aktivitas sistem imun.

Mekanisme kerja dari imunomodulator yaitu dengan caramengembalikan fungsi sistem imun yang terganggu (imunorestorasi), memperbaiki fungsi sistem imun (imunostimulasi), dan menekan respon imun (imunosupresi). Imunomodulator digunakan terutama pada penyakit imunodefisiensi, infeksi kronis dan kanker. Pemberian imunostimulan atau imunomodulator sangat diperlukan untuk mencegah penghancuran sel $\mathrm{T}$ helper $\mathrm{CD}^{+}$pada pasien yang terinfeksi bakteri dan penderita kanker (Katzung, 1995).

$$
\text { Berdasarkan hasil penelitian }
$$

inipemberian ekstrak $M$. oleifera dapat bertindak sebagai imunomodutor. Pada dosis rendah (14 dan $42 \mathrm{mg} / \mathrm{kg} \mathrm{BB}$ )mampu bertindak sebagai imunostimulator dengan mampu meningkatkan jumlah sel CD34 atau HSC.Sedangkan pada dosis tinggi $(84 \mathrm{mg} / \mathrm{kg}$ BB) dapat bertindak sebagai imunosupresor dengan mampu menurunkan jumlah sel CD34 atau HSC.

Peningkatan jumlah populasi sel CD34 ini diduga disebabkan oleh kandungan bahan aktif dari ekstrak air daun $M$. oleifera yang berupa flavonoid, saponin dan Ca. Middleton et al.(2000) mengungkapkan, flavonoid dapat memicu aktivitas Mitogen Activated Protein Kinase (MAPK). MAPK akan memicu terjadinya posporilasi berbagai protein termasuk protein transcription factor yang dibutuhkan dalam proses sintesa protein dalam proses siklus sel. Craxton et al.(1998) menambahkan MAPK dapat menginduksi terjadinya aktivasi protein transcription factor dalam hal ini $\mathrm{NF}_{-} \mathrm{B}$ (Nuclear Factor Kappa B). Sun (2010) menambahkan, $\mathrm{NF}_{-\mathrm{K}} \mathrm{B}$ merupakan faktor transkripsi yang dapat bertranslokasi ke dalam nukleus dan dapat menginduksi lebih dari 200 gen anti-apoptosis termasuk protein Bcl-2 dan Bcl-XL. Adanya protein-protein tersebut dapat memungkinkan sel untuk tetap survive dan tetap mampu melakukan proliferasi sehingga jumlah sel meningkat.

Nuhu (2010) menambahkan, senyawa flavonoid, saponin, dan $\mathrm{Ca}$ dapat ditemukan pada ekstrak air daun $M$. oleifera. Chen et al. (2003)melaporkan senyawa flavonoid, saponin, dan $\mathrm{Ca}$ dapat menginduksi terjadinya sintesis proto-oncogene seperti halnya $c$-fos dan $c$-myc. proto-oncogene ini merupakan gen regulatorik normal yang terlibat dalam pengaturan produksi dan proliferasi sel. protooncogene tersebut terlibat dalam meningkatkan konsentrasi cyclin D2 dan cyclin E, yaitu protein yang dapat mengaktifkan berbagai cyclin-dependent kinase (CDK) yang dibutuhkan dalam siklus sel. Peningkatkan konsentrasi cyclin D2 dan cyclin E ini dapat meningkatkan aktivitas proliferasi sel CD34.

Aktivitas imunosupresor diperankan oleh ekstrak daun $M$. oleifera pada dosis tinggi (84 mg/kg BB) hal ini diduga disebabkan oleh salah satu kandungan bahan aktif ekstrak $M$. oleifera Lam yang berupa saponin dalam konsentrasi tinggi diduga mampu menyebabkan apoptosis sel sehingga jumlah CD34 berkurang.Statement ini sejalan dengan 
Gao et. al., (2011) bahwa, ektrak Paris chinensis yang mengandung bahan aktif saponin dengan konsentrasi tinggi mampu meningkatkan permeabilitas membran mitokondiria sehingga akan menyebabkan teraktivasinya protein yang dapat mengaktifkan caspase 9, yang didahului dengan pelepasan sitokrom $\mathrm{c}$ dari membran mitokondria menuju sitosol. Rilisnya sitokromc dan teraktivasinya caspase 9 selanjutnya akan memicu aktivasi caspase 3 yang dapat mengaktifkan ICAD (Inhibitor of Caspase Activated DNAse) diiringi dengan meningkatnya diterminasi sel, sehingga sel akan mengalami apoptosis. Banyaknya sel yang mengalami apoptosis dapat menurunkan jumlah sel CD34 atau HSC.

Menurunnya jumlah sel CD34 juga terjadi pada kelompok perlakuan dengan model infeksi, hal ini dapat dimungkinkan terlibat dalam beberapa mekanisme.Mekanisme apoptosis sel akibat adanya agen infeksi dari bakteri patogen atau juga dapat dimungkinkan karena pada perlakuan model infeksi $S$. typhi dapat memicu berdiferensiasinya HSC ke arah meiloid maupun ke arah limfoid dalam mengatasi antigen $S$. typhi.Weinrauch \& Zychlinsky (1999) mengungkapkan, bakteri patogen seperi $S$. typhi dapat memicu terjadinya apoptosis pada host cell yang terinfeksi. Kemampuan $S$. typhi dalam menginfeksi diperankan oleh endotoksin LPS yang dimilikinya. LPS $S$. typhi dapat menekan ekpresi protein anti-apoptosis yang diperankan oleh golongan protein Bcl. Hilangnya protein anti-apoptosis akan berdampak pada terganggunya integritas membran mitokondria, yang akan berdampak pada terganggunya influks $\mathrm{Ca}$, sehingga dapat memicu apoptosis sel.

Mekanisme penurunan jumlah sel CD34 yang lain akibat berdiferensiasinya sel CD34. Hal ini dijelaskan oleh Corolin et al. (2008) bahwa HSC akan mengalami proses diferensiasi dan akan kehilangan molekul CD34, sehingga kuantitas CD34 berkurang. HSC dengan salah satu fungsinyadapat membelah menjadi stem cell limfoid progenitor dan akhirnya berkembang menjadi sel limfosit B dan T. Hoffbrand (2005) menambahkan, pada tahap awal perkembangannya HSC akan berkembang menjadi progenitor sel $\mathrm{T}$ yang kemudian berkembang menjadi sel double negatif CD4 CD8, selanjutnya sel akan berkembang menjadi singgle positif $\left(\mathrm{CD}^{+}\right.$atau $\left.\mathrm{CD}^{+}\right)$ tergantung pada reaksi TCR dengan kelas MHC. Jika TCR berikatan dengan MHC kelas I, maka akan memicu diferensiasi ke prekursor sel T sitotoksik $\left(\mathrm{CD}^{+}\right)$, sedangkan ikatan TCR dengan MHC kelas II akan memicu diferensiasi ke prekursor sel $\mathrm{T}$ helper $\left(\mathrm{CD} 4^{+}\right)$. Ikatan TCR dengan kelas MHC I atau II ditentukan oleh jenis antigen yang diproses oleh sistem imunitas.

\section{Kesimpulan}

Ekstrak daun Moringa oleifera Lam dapat bertindak sebagai imustimulator dengan mampu meningkatkan populasi HSC (CD34) pada mencit yang diinfeksi Salmonella typhi, namunpada pemberian ekstrak daun $M$. oleifera Lam dengan dosis rendah (14 dan 42 $\mathrm{mg} / \mathrm{kg}$ BB)lebih efektif bila dibandingkan dengandosis tinggi (84 mg/kg BB). Bahkan, pada dosis tinggi $(84 \mathrm{mg} / \mathrm{kg}$ BB) dapat berindak sebagai imunosupresor.

\section{Acknowledgment}

Penelitian ini didanai oleh

Muhaimin Rifa'i, Ph.D., Med. Sc. dalam hal pengadaan hewan coba dan antibodi.

\section{Daftar Pustaka}

Chen HL., Li DF., Chang BY., Gong, LM., Piao XS., Yi G.F., and Zhang JX. 2003. Effects of Lentinan on Broiler Splenocyte Proliferation, Interlaukin-2 Production, dan Signal Transduction. Journal Poultry Science: 82:760-766

Craxton A., Shu G., Graves J.D., Saklatvala J., Krebs E.G., and Clark, EA. 1998.p38 MPAK is Required for CD40-Induced Gene Expression and Proliferation in B Lymphocytes. Journal of Immunology. 161:3225-3236.

Diepen AV., Gevel JSV., Koudijs MM., Ossendrop F., Beekhuizen H., Janssen R., and Dissel JTV. 2005. Gamma Irradiation or CD4+-T-Cell Depletion Causes Reactivation of Latent Salmonella enterica Serovar Typhimurium Infection in $\mathrm{C} 3 \mathrm{H} / \mathrm{HeN}$ Mice. Journal Infection and Immunity. 75(3):2857-2862

Eckmann L., Martin., andKagnof F. 2001. Cytokines in Host Defense Against Salmonella. Journal Mocrobes and Infection. 3:1191-1200 
Gao L., Li FR., Jiao P., Yang MF., Zhou XJ., Si YH., Jiang WJ., and Zheng T. 2011. Paris chinensis Dioscin Induces G2/M Cell Cyle Arrest and Apoptosis in Human Gastric Cancer.Word Journal Gastroenterology.17(39): 4389-4395.

Gupta A., Gautam MK., Singh RK., Kumar MV., Rao CV., Goel RK., and Anupurba S. 2010. Immunomodulatory Effect of Moringa oliefera Lam. Extract on Cyclophophamide Induced Toxicity in Mice. Journal of Experimental Biology. 48: 1157-1160

Hoffbrand AV., Pettit, JE.,\& Moss PA. 2005. Hematology. Jakarta,: EGC Kedokteran, 285-290.

Kasolo JN., Bimenya GS., Ojok L., Ochieng J., and Jasper WO. 2010. Phytochemicals and uses of Moringa oleifera leaves in Ugandan rural communities. Journal of Madicinal Plant Reseacrch. 4(9): 753757

Katzung BG. 1995. Basic and Clinical Pharmacology ${ }^{\text {6thEd }}$. Prentice, Hall International Inc, 157.

Middleton E., Kandaswami C., and Theoharides TC. 2000. The Effects of Plant Flavonoids on Mammalian Cells: Implications for Inflammation, Heart Disease, dan Cancer. Journal Pharmacol.52(4): 673-751.

Nuhu F. 2010. Effect of Moringa Leaf Meal (MOLM) on Nutrient Digestibility, Growth, Carcass and Blood Indices of Weaner Rabbits.Thesis.Kwame Nkrumah University of Science and Technology, Kumasi, 87.

Pui CF., Wong WC., Chai LC., Tunung R., Jeyaletchumi P., Hidayah N., Ubong A., Farinazleen MG., Cheah, YK., and Shon R. 2011. Salmonella : A Foodborne Pathogen. Review Article International Food Research Journal. 18: 465-473

Sudha P., Asdaq SMB., Dhamingi SS., and Chandrakala $\quad$ GK. 2010. Immunomodulatory Activity of Methanolic Leaf Extract Of Moringa oleifera In Animals. Journal Pharmacol. 54(2): 133-140

Sun OC. 2010. Studies of The Anti-Cancer Potential of Flavonoids in Human Nasopharyngeal Carcinoma Cells. Thesis.Master of Science, National University of Singapore, Singapore, 53.
Torres AV., Carson JJ., Mastroeni P., Ischiopoulus H.,and Fang FC. 2000. Antimicrobial action of the NADPH phagocyte oxidase and inducible nitric oxidase synthase in experimental salmonellosis. Effect on microbial killing by activated peritoneal macrophages in vitro. J Exp Med. 192(2) : 227-236

Weinrouch Y and Zynchlinsky A. 1999.The Induction of Apoptosis by Bacterial Pathogens.Annual Reveiw of Microbiology.53(10): 155-187.

Wiedosari E. 2007. Peranan Imunomodulator Alami (Aloe vera) dalam Sistem Imunitas Seluler dan Humoral. Jurnal Wartazoa. 17(4): 165-171

Zang LX., Jeza, Vektor T., and Pan Q.. 2008. Salmonella typhi Human Pathogen to a Vaccine Vector. Journal Review Cellular and Molecular Immunology. 5(2): 91-97 
Tabel 1. Pengelompokan Dosis dan Model Faktor Perlakuan terhadap Hewan Coba

\begin{tabular}{|c|l|}
\hline Dosis M. oliefera & \multicolumn{1}{|c|}{ Model Faktor Perlakuan } \\
\hline \multirow{2}{*}{ K (0 $\mathbf{~ m g / k g ~ B B )}$} & Non-infeksi S. typhi \\
\cline { 2 - 2 } & Infeksi S. typhi \\
\hline \multirow{2}{*}{ P1 (14 $\mathbf{~ m g / k g ~ B B ) ~}$} & Non-infeksi S. typhi \\
\cline { 2 - 2 } & Infeksi S. typhi \\
\hline \multirow{2}{*}{$\mathbf{P 2}(\mathbf{4 2} \mathbf{~ m g / k g ~ B B )}$} & Non-infeksi S. typhi \\
\cline { 2 - 2 } & Infeksi S. typhi \\
\hline \multirow{2}{*}{$\mathbf{P 3}(\mathbf{8 4} \mathbf{~ m g / k g ~ B B )}$} & Non-infeksi S. typhi \\
\cline { 2 - 2 } & Infeksi S. typhi \\
\hline
\end{tabular}

Tabel 2. Ringkasan Analisis SPSS two-way ANOVA (Analysis of Variance) melalui program SPSS 16.0.

\begin{tabular}{|l|r|r|r|r|c|}
\hline \multicolumn{1}{|c|}{ Source } & $\begin{array}{c}\text { Type III Sum of } \\
\text { Squares }\end{array}$ & df & Mean Square & \multicolumn{1}{c|}{ F } & Sig. \\
\hline Corrected Model & $1.896 E 12 a$ & 7 & $2,71 E+14$ & 56.896 & .000 \\
\hline Intercept & $9,70 E+15$ & 1 & $9,70 E+15$ & $2,04 E+06$ & .000 \\
\hline DOSIS & $4,86 E+14$ & 3 & $1,62 E+14$ & 34.053 & .000 \\
\hline FAKTOR & $8,70 E+14$ & 1 & $8,70 E+14$ & 182.773 & .000 \\
\hline DOSIS $*$ FAKTOR & $5,39 E+14$ & 3 & $1,80 E+14$ & 37.779 & .000 \\
\hline Error & $1,14 E+14$ & 24 & $4,76 E+12$ & & \\
\hline Total & $1,17 E+16$ & 32 & & & \\
\hline Corrected Total & $2,01 E+15$ & 31 & & & \\
\hline
\end{tabular}

Ket: Sig $<0.05=$ berbeda antara kelompok perlakuan. 
Gambar 1. Hasil analisis flowcytometri sel CD34 pada bone marrow.

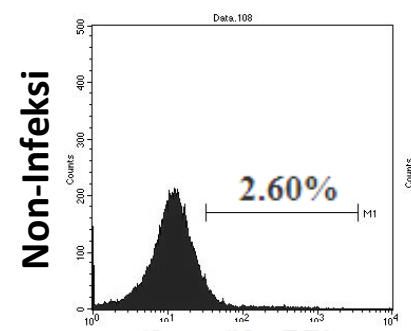

$(0 \mathrm{mg} / \mathrm{Kg} \mathrm{BB})$

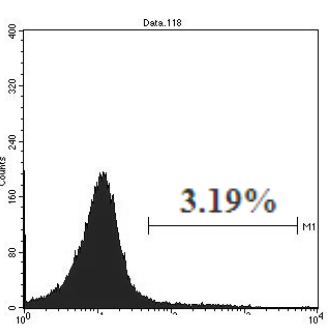

(14 mg/Kg BB)

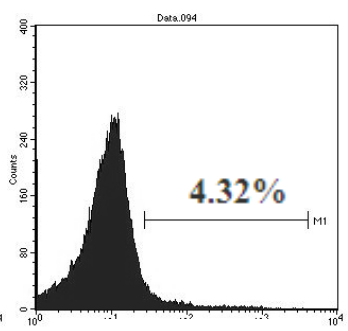

$(42 \mathrm{mg} / \mathrm{Kg} \mathrm{BB})$

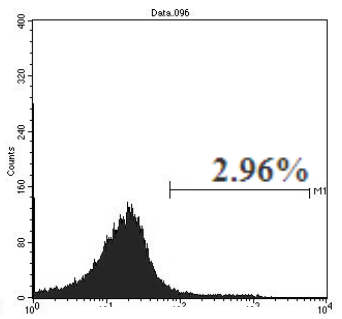

$(84 \mathrm{mg} / \mathrm{Kg} \mathrm{BB})$
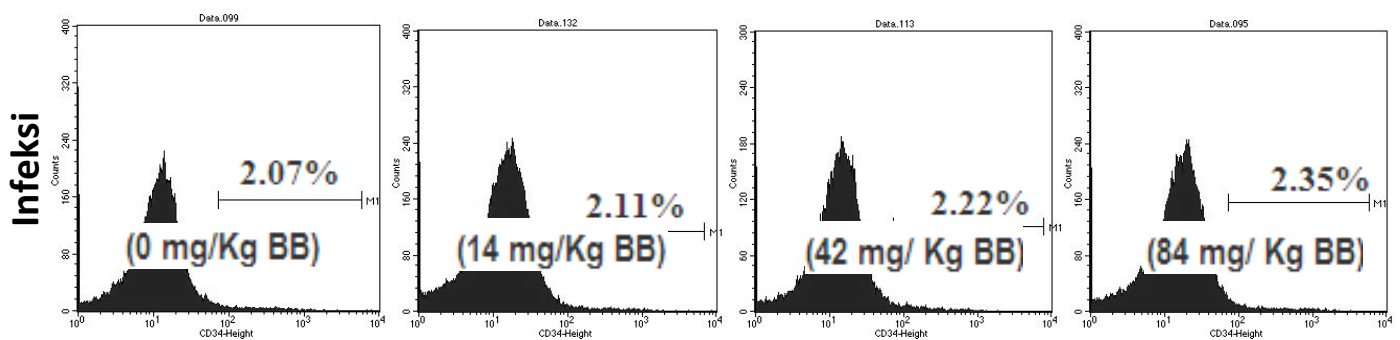

\section{CD34 $^{+}$}

Gambar 1. Hasil analisis flowcytometri sel $\mathrm{CD} 34^{+}$pada bone marrow.

Gambar 2. Hasil analisis uji lanjut Tukey 0.05 terhadap jumlah sel CD34

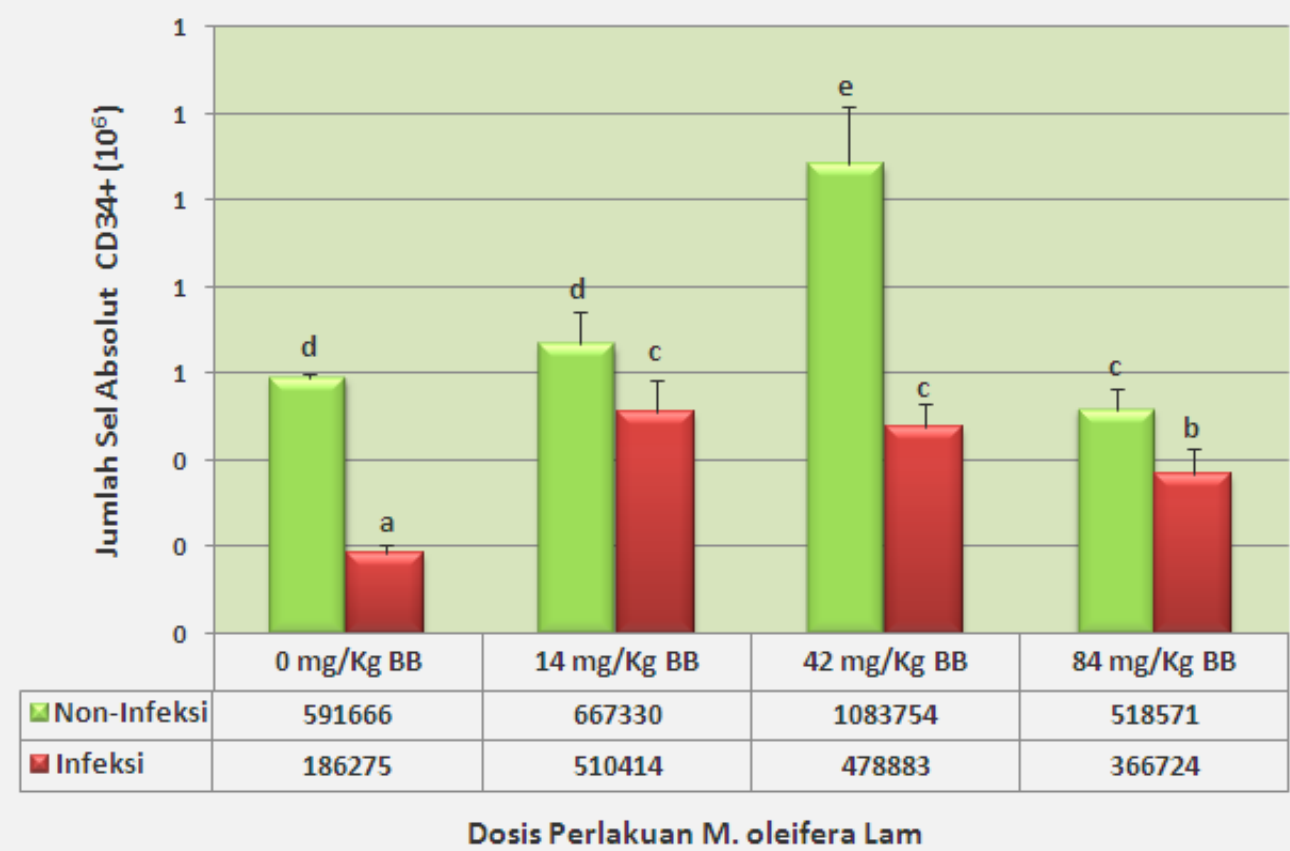

Gambar 2. Hasil analisis uji lanjut Tukey 0.05 terhadap jumlah sel CD34

Keterangan: grafik yang diikuti huruf yang tidak sama menunjukan berbeda nyata pada (P-Value 0.05). 